\title{
The effects of immunization with recombinant Sm14 (rSm14) in reducing worm burden and mortality of mice infected with Schistosoma mansoni
}

\author{
Os efeitos da imunização com Sm14 recombinante (Sm14r) na redução da carga de \\ vermes e na mortalidade de camundongos infectados com Schistosoma mansoni
}

Fábio Ribeiro', Cristiane dos Santos Vieira ${ }^{1}$, Adriana Fernandes' ${ }^{1}$, Neusa Araújo' and Naftale Katz ${ }^{1}$

\begin{abstract}
To investigate whether mice immunization with the recombinant form of a $14.7 \mathrm{KDa}$ Schistosoma mansoni protein ( $r S m 14$ ) confers protection against a S. mansoni lethal challenge infection, $r S m 14-i m m u n i z e d$ mice were challenged with different cercarial burdens. A significant protection was detected in immunized mice challenged with 100 or 1,000 S. mansoni cercariae when compared with their controls $(p<0.004$ and $p<0.01$ respectively). Differently from previous report, none of the mice from the control group (not immunized and infected with 1000 cercariae) died before the $30^{\text {th }}$ day post-infection. A direct correlation between the number of challenge cercariae and the precocity of mice death was found. IgM anti-rSm14 antibodies were significantly produced $(p<0.05)$ mainly in the groups of immunized mice infected with 500 or 1000 cercariae. IgG and IgA anti-rSm14 antibodies were not significantly detected. In Western immunoblots, all mice sera showed a specific antibody response with a $14.7 \mathrm{KD}$ a antigen being reacted with particular intensity in sera from immunized mice. The results show that immunization with $\mathrm{rSm} 14$ reduced mice worm burden independently of the cercariae load of challenge infection. No correlation was found between serum antibodies and worm burden reduction. In relation to cercarial load and the rate and precocity of mice mortality a direct correlation was found.

Key-words: Schistosoma mansoni. recombinant Sm14. Immunization. Fatty acid binding protein.
\end{abstract}

Resumo A fim de investigar se a imunização de camundongos com a proteína recombinante de14,7 KDa (Sm14r) de Schistosoma mansoni confere proteção contra uma infecção letal por S. mansoni, camundongos imunizados com Sm14r foram infectados com diferentes cargas de vermes. Uma proteção significativa foi demonstrada nos camundongos imunizados e infectados com 100 ou 1.000 cercárias de S. mansoni quando comparados com os controles ( $p<0,004$ e $p<0,01$ respectivamente). Diferentemente de resultados anteriores, nenhum camundongo do grupo controle (não imunizado e infectado com 1.000 cercárias) morreu antes do $30^{\circ}$ dia após infecção. Uma correlação direta entre o número de cercárias e o tempo de morte dos camundongos foi detectada. Anticorpos IgM anti-Sm14r foram produzidos significativamente $(p<0,05)$, principalmente, nos grupos de camundongos imunizados e infectados com 500 ou 1.000 cercárias. Anticorpos IgG e IgA antiSm14r não foram produzidos em quantidades significativas. Os testes de immunoblots demonstraram que todos os soros de camundongos revelaram uma banda específica de aproximadamente 14,7 KDa, e com maior intensidade nos soros dos camundongos imunizados. A maior reatividade foi encontrada no soro no período da terceira imunização. Os resultados mostram que imunização com Sm14r reduz a carga de vermes independentemente da carga de cercárias da infecção. Nenhuma correlação foi encontrada entre tipos de anticorpos e redução da carga de vermes. Uma correlação direta foi encontrada em relação a carga de cercárias e a taxa e precocidade da mortalidade dos camundongos.

Palavras-chaves: Schistosoma mansoni. Imunização. Sm14 recombinante. Proteínas carreadoras de ácidos graxos.

1. Laboratório de Esquistossomose do Centro de Pesquisas René Rachou da Fundação Oswaldo Cruz, Belo Horizonte, MG.

Suporte financeiro: FIOCRUZ/CNPq e FAPEMIG.

Endereço para correspondência. Dr. Fábio Ribeiro. Laboratório de Esquistossomose, Centro de Pesquisas René Rachou. Av. Augusto de Lima 1715, 30190-002 Belo Horizonte, MG, Brasil.

Tel: 553132953566 , Fax: 553132953115

E-mail: fribeiro@cpqrr.fiocruz.br

Recebido para publicação em 20/06/2001. 
The study of candidate antigens for a vaccine against schistosomiasis is a subject that has aroused great interest, mainly in the last two decades. Immunization with secreted and excreted antigens (SE) derived from Schistosoma mansoni adult worms conferred protection against lethal infection when mice were challenged with 1,000 S. mansoni cercariae $^{13}$. The complete sequence of nucleotides from a Sm14 expressed in Escherichia coli has already been determined. This protein contains a sequence of aminoacids with significant homology to proteins of fatty acids binding proteins (FABPs) family ${ }^{7}$. The protective activity of recombinant $\mathrm{Sm} 14$ (rSm14) in immunized mice challenged with S. mansoni cercariae has been shown ${ }^{12}$. The authors reported that similar protection levels were detected in immunized mice with rSm14 in the presence or absence of Freund's complete adjuvant.

As Sm14 is one of the component antigens of SE, it would be important to evaluate whether this protein has the same prophylactic potential of SE against lethal infection by S. mansoni. Thus, an experimental protocol was carried out in which mice were previously immunized with the recombinant protein and challenged with different S. mansoni cercarial burdens, including those expected to be lethal.

\section{MATERIAL AND METHODS}

Parasite and hosts. Female Swiss mice were used for immunization with rSm14 and posterior challenge infection with S. mansoni cercariae (LE strain) kept routinely on Biomphalaria glabrata snails, at our laboratory.

Obtention and concentration of cercariae. B. glabrata snails infected with $S$. mansoni were put into a beaker with dechlorinated water and exposed to artificial light for 2 hours. The discharged cercariae were concentrated according to the technique previously described ${ }^{8}$.

Infection and recovery of parasites. Mice were infected with different cercarial burdens by subcutaneous route ${ }^{9}$. Perfusion of mice for worm recovery was carried out as prescribed $^{9}$. In summary, after sacrifice of the animals by cervical fracture, the viscera were exposed, the portal vein was torn and the terminal portion of the large intestine was tied up. Mice were then perfused through the thoracic aorta artery and also through the hepatic hilum.

Recombinant Sm14 (rSm14). Expression and purification of rSm14 has been carried out at the Instituto Butantan, São Paulo, Brazil. Briefly, a BL21-DE3 Escherichia coli colony transformed with plasmid
pRSET6xHis was induced in culture medium in presence of ampicillin $100 \mu \mathrm{g} / \mathrm{ml}$ plus $1 \mathrm{mM}$ Isopropyl $\beta$-Dthiogalactopyranoside (IPTG) for 3 hours at $37^{\circ} \mathrm{C}$. Cell recovery was carried out by centrifugation at 5,000rpm for 15 minutes. Cells were suspended, and submitted to French pressure at 2,000 GAGE 3X. The lysate was centrifuged at $5,000 \mathrm{rpm}$ for 15 minutes at $4^{\circ} \mathrm{C}$. The soluble cell-free extract was centrifuged at 5,000rpm for 15 minutes, filtered and used for purification of rSm14 using a $5 \mathrm{ml} \mathrm{Ni-Sepharose} \mathrm{column} \mathrm{(Armershan}$ Pharmacia Biotech, England, U.K).

Experimental protocol. Mice were divided into seven groups of 12 animals each. Mice were immunized (footpad injection) with 3 doses of rSm14 (20 $\mathrm{gg})$ on days 0,7 and 21 . Forty-five days after the last immunization, the animals were infected with 100,500 or 1,000 cercariae. Control groups received phosphate buffer saline (PBS) on the same days of the above immunization protocol, and were infected with 100, 500 or 1,000 cercariae, respectively, on the same date for infection of immunized groups (Table 1). One group of mice was immunized with rSm14 $(10 \mu \mathrm{g})$, on the same

Table 1 - Protective activity of rSm14 in mice previously immunized and challenged with different S. mansoni cercarial burdens.

\begin{tabular}{lcccc}
\hline Immunization Protocol & Number of cercariae & Worm recovery Mean \pm SD & Protection $\%$ & Significance level \\
\hline rSm14 $(3 \times 10 \mu \mathrm{g})$ & 100 & $17.6 \pm 8.6$ & 36.9 & 0.05 \\
rSm14 $(3 \times 20 \mu \mathrm{g})$ & 100 & $14.1 \pm 4.9$ & 49.5 & 0.004 \\
PBS $(3 \times)$ & 100 & $27.9 \pm 5.3$ & - & \\
rSm14 $(3 \times 20 \mu \mathrm{g})$ & 500 & $93.7 \pm 19.8$ & 7.8 & $\mathrm{NS}^{*}$ \\
PBS $(3 \times)$ & 500 & $101.7 \pm 18.0$ & - & \\
rSm14 $(3 \times 20 \mu \mathrm{g})$ & 1.000 & $181.0 \pm 65.2$ & 41.2 & 0.01 \\
PBS $(3 \times)$ & 1.000 & $335.0 \pm 94.5$ & - & \\
\hline
\end{tabular}

${ }^{*} \mathrm{NS}=$ Not significant

date of the other groups. Forty-five days after challenge infection, half of each group was sacrificed for worm burden evaluation. The other half was kept under observation to evaluate the kinetic of mortality in rSm14immunized mice and respective controls bearing a heavy infection with S. mansoni.

Enzyme-linked immunosorbent assay (ELISA). Mice were anesthetized with ether for blood collection, through the orbital plexus throughout the experiments, or through the brachial vein, before perfusions. Blood collected was kept on ice for 30 minutes and later for 30 minutes at room temperature. Sera were centrifuged, aliquoted and stored at $-20^{\circ} \mathrm{C}$ until use.

Flat-bottomed microtiter plates (Maxsorp, Nunc) were coated with $\mathrm{rSm} 14(1 \mu \mathrm{g} /$ well) in carbonate buffer $\mathrm{pH} 9.6$ overnight. Microtiter plates were then washed 
$3 \mathrm{X}$ in phosphate buffer saline containing $0.05 \%$ Tween 20 (PBST20) and non-specific binding sites were blocked with $2.5 \%$ non-fat milk in PBST20 for 1 hour at $37^{\circ} \mathrm{C}$. Plates were washed $3 X$ with PBST 20 . Sera were diluted $1 / 100$ in PBST20 and incubated for 1 hour at $37^{\circ} \mathrm{C}$. After incubation, plates were washed $3 X$ with PBST20 and then a second goat anti-mouse IgG, IgM or IgA antibody conjugated with peroxidase (Sigma, St. Louis, Mo, USA) was added at dilution 1/3,000. After a new incubation at $37^{\circ} \mathrm{C}$ for 1 hour, the plates were once more washed $3 \mathrm{X}$, and substrate 2,2'-azino-bis(3-ethylbenz-thiazoline-6sulfonic acid (ABTS - Sigma, St. Louis, Mo, USA) was added. Readings were taken using ELISA reader (BIORAD Mod. 3550) at 405nm.

Western-blotting. rSm14 was applied into 15\% polyacrylamide gel containing sodium dodecylsulphate (SDS-PAGE), as described ${ }^{4}$. SDS-PAGE gels were electrotransferred onto nitrocellulose membrane (Armershan Pharmacia Biotech, England, UK). After transferring, membrane was stained with Ponceau's solution and then sliced into strips. Membrane strips were blocked with $5 \%$ skimmed milk in transblotting solution containing $0.05 \%$ Tween 20 (TBST20) for 2 hours. Strips were then washed $3 X$ with TBST20 for 10 minutes. Mice sera were added at $1 / 100$ dilution at room temperature for 1 hour. After washing in TBST20, a secondary alkaline phosphatase-labeled goat anti-mouse IgG (Promega, Madison, WI, USA) was added at dilution 1/5,000 for 1 hour at room temperature. Development was carried out by addition of $p$-nitroblue tetrazolium chloride and 5-bromo-4chloro-3-indolyl phosphate (NBTBCIP - Bio-Rad Lab., CA, USA) as substrate. Reaction was interrupted with milli-q water.

Statistical analysis. Percentage of protection conferred in immunized groups was assessed according to the following formula: $P=[(C-V) \backslash C] \times 100$ where $C$ represents the mean number of parasites in control animals, $V$ represents the mean number of parasites in vaccinated animals. Analysis of variance test with statistical level of significance set at $P<0.05$ was used for the studied groups.

\section{RESULTS}

Protection against infection. Mice immunized with rSm14 (10 or $20 \mu \mathrm{g}$ ) and infected with 100 cercariae showed $36.9 \%$ and $49.5 \%$ protection respectively in relation to the non-immunized control group. rSm14immunized group and challenged with 500 cercariae did not show significant worm burden reduction. However, those infected with 1,000 cercariae presented $41.2 \%$ of worm burden reduction $(p<0.01)$ (Table 1).
Mortality rate. The group of mice immunized with $20 \mu \mathrm{g} / \mathrm{rSm} 14$ and challenged with 100 S. mansoni cercariae presented on day 66 after infection $14 \%$ of dead animals, whereas the control group reached $50 \%$ mortality (Figure 1). Immunized group and infected with 500 cercariae (which did not show significant worm burden reduction) presented, on day 59 after infection, a mortality rate of $42.8 \%$, whereas the control group

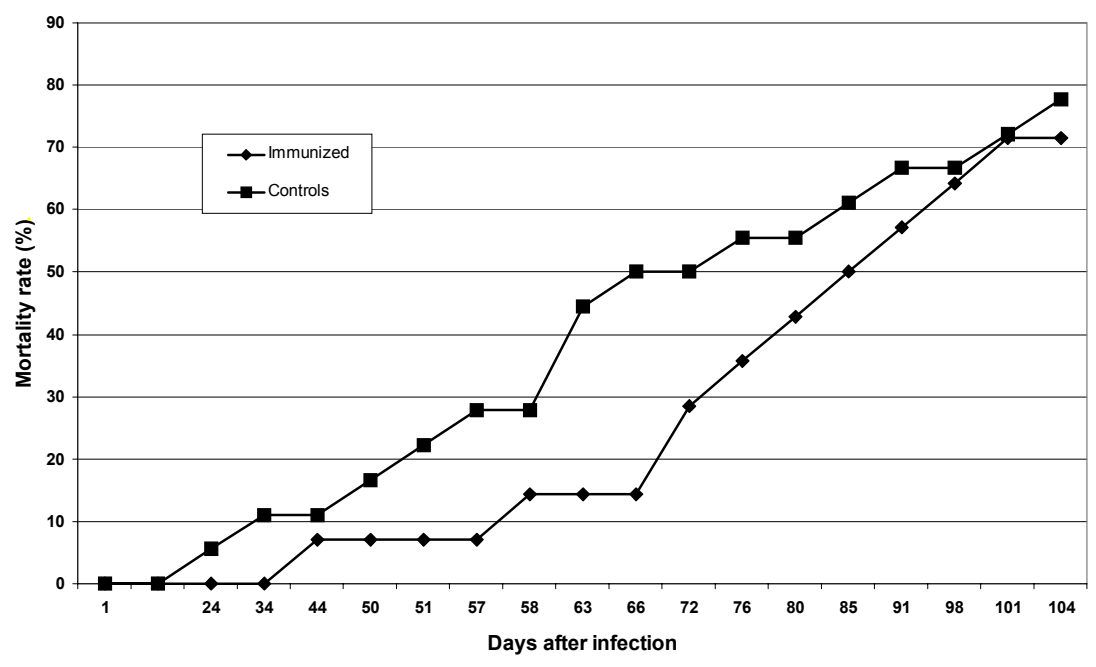

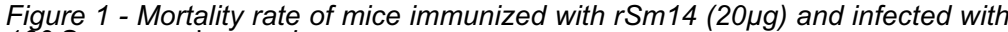
100 S. mansoni cercariae.

showed $76.9 \%$ (Figure 2). rSm14-immunized mice and challenged with 1000 cercariae demonstrated that 48 days after infection the mortality rate was $38 \%$ against $82 \%$ mortality for the control group (Figure 3). Statistical analysis of the mortality rate among the immunized and control groups showed no significant differences probably due to the reduced number of surviving mice along the experiment. Days that represent 50 or $90 \%$ mortality of immunized groups and respective controls showed that a direct correlation has been found between the number 


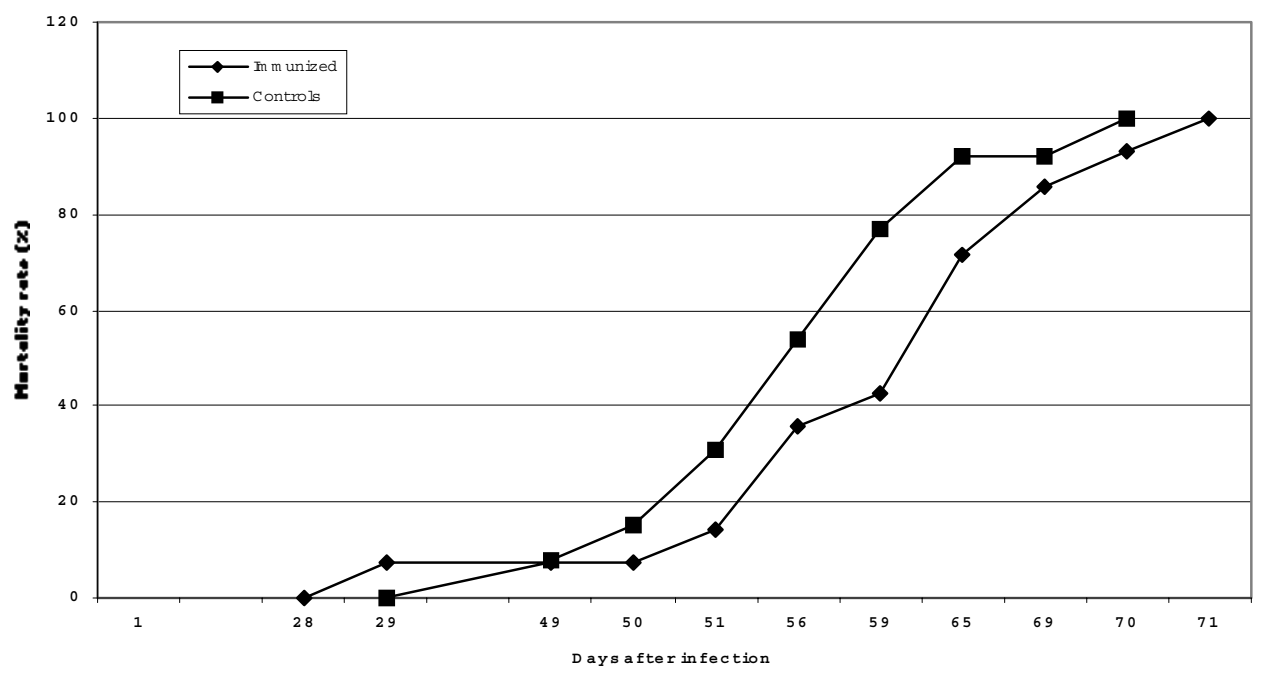

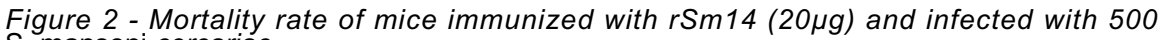
S. mansoni cercariae.

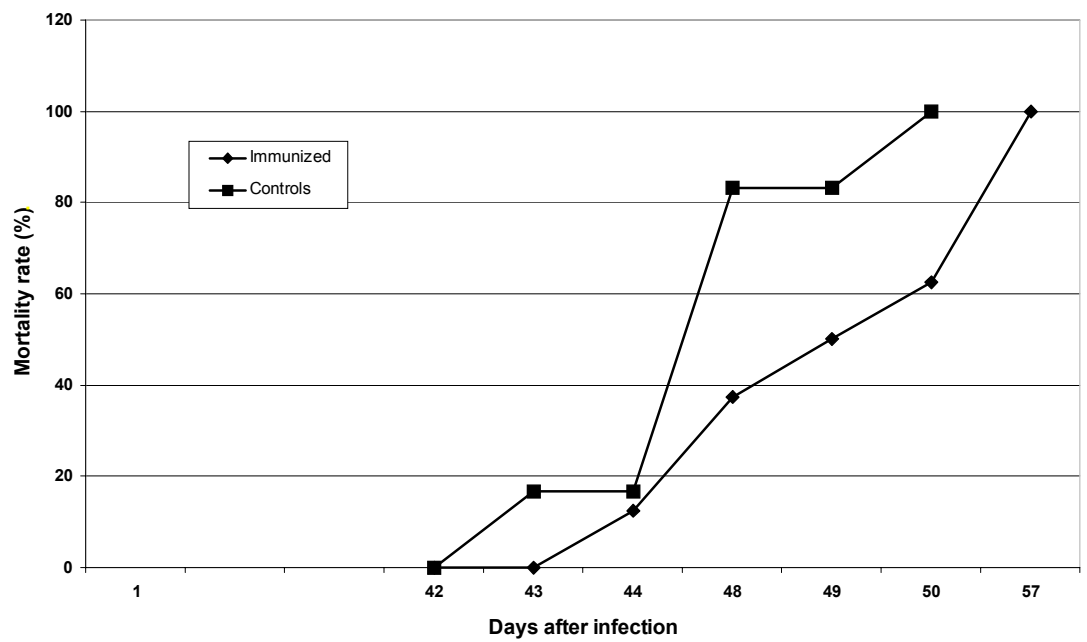

Figure 3 - Mortality rate of mice immunized with rSm14 (20 $\mu \mathrm{g})$ and infected with $1.000 \mathrm{~S}$. mansoni cercariae.

of cercariae of the challenge infection and the precocity of the animals death. It is interesting to remark, this correlation has been found not only in the two immunized and protected groups, but also in the non-protected one (Tabela 2).

Evaluation of the immune response - ELISA: it was not detected any significant difference in $\lg A$ and $\lg G$ anti-rSm14 $(20 \mu \mathrm{g})$ antibody levels in sera from immunized mice collected 45 days after infection in relation to the control groups. There was no difference in IgG anti-rSm14 antibody levels between 10 or $20 \mu \mathrm{g}-$ immunized groups (data not shown). However, IgM anti-
rSm14 antibody levels in sera from mice immunized with rSm14 $(20 \mu \mathrm{g})$, collected 45 days after infection with 500 or 1,000 cercariae, were statistically significant when compared with non-immunized mice groups (Figure 4). Western blotting: as can be seen in (Figura 5), immunoblotting demonstrated that sera of mice collected at the same date of the third immunization showed the highest reactivity against $\mathrm{rSm} 14$ (lane 7). Sera from

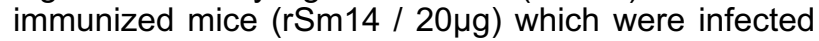
with 100 cercariae as well as their respective controls presented only a slight reactivity. However, sera

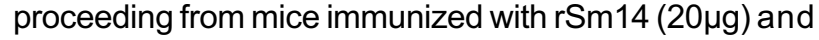


Table 2 - Effect of immunization with rSm14 on mortality time after infection with different $\mathrm{S}$. mansoni cercarial burdens.

\begin{tabular}{lcccr}
\hline Mortality & & $\begin{array}{c}\text { Group infected } \\
\text { with 100 cercariae }\end{array}$ & $\begin{array}{c}\text { Group infected } \\
\text { with 500 cercariae }\end{array}$ & $\begin{array}{c}\text { Group infected } \\
\text { with } 1000 \text { cercariae }\end{array}$ \\
\hline M50 & C & 66 & 55 & 45 \\
& I & 85 & 60 & 49 \\
M90 & C & $>104$ & 64 & 49 \\
Protection \% & I & $>104$ & 70 & 57 \\
\hline
\end{tabular}

M50 = mortality of $50 \%$ of the animals expressed in days. M90 = mortality of $90 \%$ of the animals

expressed in days. $\mathrm{C}=$ controls. $\mathrm{I}=$ immunized mice

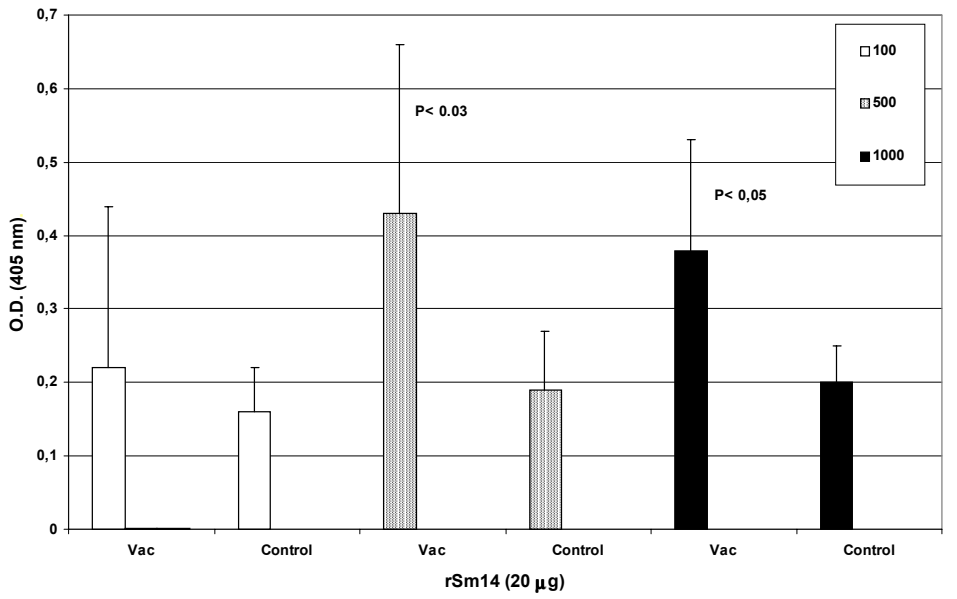

Figure 4 - IgM anti-rSm14 antibody levels in sera from immunized mice.

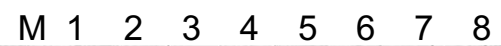

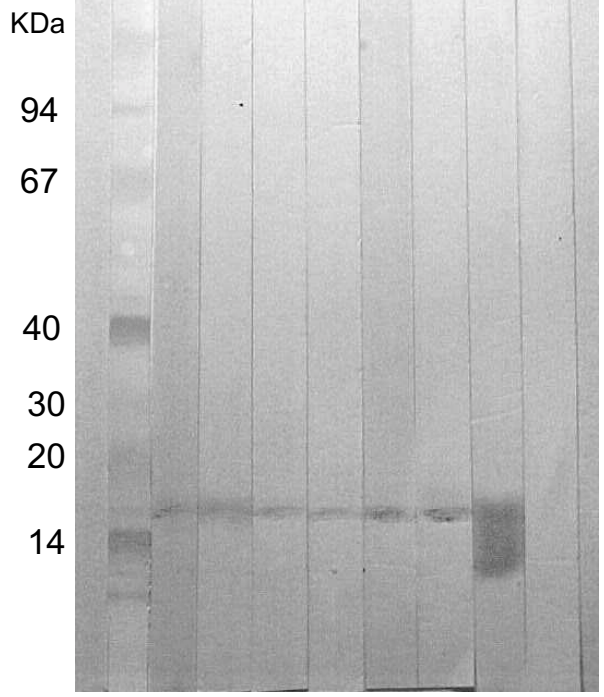

Figure 5 - Western Immunoblotting of rSm14 recognition by immune or normal mice sera.

$M=$ Molecular weight. 1) $20 \mu \mathrm{g}+$ Inf. 100

cercariae. 2) $20 \mu \mathrm{g}+$ Inf. 500 cercariae. 3

$20 \mu \mathrm{g}+$ Inf. 1000 cercariae. 4) Inf. 100 
infected with 500 cercariae (lane 5) reacted against the rSm14 antigen showing a reactive band with approximately $14 \mathrm{KDa}$. Conversely, the respective control group demonstrated light reactivity.
In relation to the group infected with 1,000 cercariae, the non-immunized group (lane 6) presented higher activity when compared with the rSm14-immunized group (lane 3).

\section{DISCUSSION}

In the present report we have studied the humoral response induced in rSm14-immunized mice as well as the capacity of the recombinant protein in protecting mice from different challenge infections $(100,500$ or 1,000 cercariae) including that supposed to be lethal for the animals up to $30^{\text {th }}$ day after infection. On the contrary to findings previously reported in the literature ${ }^{13}$, our results have demonstrated that $S$. mansoni infection of mice with 1,000 cercariae did not lead the animals to death up to the $30^{\text {th }}$ day of infection. The diverging results between two similar infection protocols could be perhaps explained by the use of a $S$. mansoni strain, which has been maintained at the laboratory of the Centro de Pesquisas René Rachou, Belo Horizonte, Brazil, routinely, for more than 30 years. The strain used in our experiments may have had its virulence altered after maintenance for all these years in genetically different hosts from that used by other authors. This diminished virulence could develop a less drastic pathogenesis in mice. The immunization schedule used was able to attain a significant protection (about 50\%) in the group of animals immunized with $\mathrm{rSm} 14(20 \mu \mathrm{g})$ and infected with 100 or 1,000 cercariae, thus suggesting that there was no correlation between the infectious burden and worm burden reduction conferred by the immunization. For unknown reasons, the immunized group and that infected with 500 cercariae did not show significant protection when compared to the control group. As far as the mortality rate is concerned, a notable delay on M50 was detected in the immunized animal groups infected with 100,500 or 1,000 cercariae. It is worthwhile to note that when a higher number of cercariae were inoculated the mortality rate of mice not only was more precocious, but also higher. The same trend was observed in M90 to both immunized and control group. In regard to mortality rate the results showed that in spite of the groups of immunized mice challenged with 100,500 or 1.000 S. mansoni cercariae had presented on day 66 (14\% of dead animals whereas the control group reached $50 \%$ of mortality), 59 (42.8\%, whereas the control group showed $76.9 \%$ mortality) and 48 (38\% against $82 \%$ mortality) respectively, statistical analysis of the mortality rate among the immunized and control groups showed significant differences probably due to the reduced number of surviving mice during the experiment. ANOVA simulation tests using groups formed by 15 mice demonstrated significant differences among immunized and infected groups and their respective controls.

Previous studies have demonstrated the role of the host's humoral response in the elimination mechanisms of S. mansoni from mice submitted to different immunization protocols ${ }^{11562}$. Immunization of mice with rSm14 did not produce significant IgG and IgA anti-rSm14 antibody levels. However, significant IgM anti-rSm14 antibody levels could be detected, mainly in the groups of immunized mice and infected with 500 or 1,000 cercariae.

Other studies using human models, have detected low but significant IgM anti-rSm14 antibody levels in human serum from individuals in different clinical forms (compensated hepatosplenic and individuals termed normal endemic who were stoolnegative in repeated examinations but living in continuous contact with contaminated water) but IgM anti-rSm14 antibody levels were not significant in human serum from patients at intestinal, acute or decompensated hepatosplenic ${ }^{1}$. Immunoblotting showed that sera of mice collected at the same date of the third immunization presented the highest reactivity against $r S m 14$. Sera from immunized mice that were infected with 100 cercariae presented a slight reactivity whereas its control group was negative. Sera from mice immunized with rSm14 $(20 \mu \mathrm{g})$ and infected with 500 cercariae reacted against rSm14 showing a reactive band. Its respective control group demonstrated a light reactivity. The lack of correlation between protection and IgG, IgM or IgA antibody levels could be due to immunization of mice with rSm14 leads rather to a cellular immune response than a humoral immune response. The study on cytokine profile to detect IFN- $\gamma$ or TNF- $\alpha$ and lymphoproliferative assays would lead to a better understanding of the effector mechanisms involved in worm burden reduction of rSm14-immunized mice. According to some researchers, optimal vaccination against S. mansoni requires the induction of both humoral and cellmediated immune mechanisms ${ }^{3}{ }^{14}$. In summary, although it has been observed up to $50 \%$ of protection in $\mathrm{rSm} 14$-immunized mice challenged with 100 or 1,000 cercariae, no correlation was found between mortality rates and protection, but in all three groups immunization apparently induced a delay in mortality rates. It was not found either a correlation between protection and $\lg G, \lg M$ or $\lg A$ antibody levels. However, a direct correlation was achieved between cercarial burden and the rate and precocity of mice mortality. Further studies must be carried out in order to clarify whether immunization of mice with rSm14 leads to production of IgE antirSm14 antibodies as well as a rSm14-derived cellular immune response in mice. 


\section{REFERENCES}

1. Brito CFA, Fonseca CT, Goes AM, Azevedo V, Simpson AJG Oliveira SC. Human IgG1 and IgG3 recognition of Schistosoma mansoni $14 \mathrm{KDa}$ fatty acid-binding protein. Parasite Immunology 22: 41-48, 2000.

2. Curtis RHC, Fallon PG, Doenhoff MJ. Sm480: a high molecular weight Schistosoma mansoni antigen associated with protective immunity. Parasite Immunology 18: 149-157, 1996.

3. Jankovic D, Wynn TA, Kulberg MC, Hieny S, Caspar P, James S, Cheever AW, Sher A. Optimal vaccination against Schistosoma mansoni requires the induction of both B cell-and IFN- $\gamma$ dependent effector mechanisms. Journal of Immunology 162: 345351, 1999.

4. Laemmli UK. Cleavage of structural proteins during the assembly of the head of bacteriophage T4. Nature 227: 685-690, 1970.

5. Mangold BL, Dean DA. Passive transfer with serum and IgG antibodies of irradiated cercariae-induced resistance against Schistosoma mansoni in mice. Journal of Immunology 136: 26442648, 1986.

6. Mangold $B L$, Dean DA. The role of $\lg G$ antibodies from irradiated cercariae-immunized rabbits in the passive transfer of immunity to Schistosoma mansoni-infected mice. American Journal of Tropical Medicine and Hygiene 47: 821829, 1992.

7. Moser D, Tendler M, Griffiths G, Klinkert Mo-Quen. A 14-KDa Schistosoma mansoni polypeptide is homologous to a gene family of fatty acid binding proteins. Journal of Biological Chemistry 266: 8447-8454, 1991
8. Peters PA, Warren K. A rapid method of infecting mice and other laboratory animals with Schistosoma mansoni: subcutaneous injection. Journal of Parasitology 55: 558, 1969.

9. Pellegrino J, Macedo DG. A simplified method for the concentration of cercariae. Journal of Parasitology 41: 329-330, 1956.

10. Pellegrino J, Siqueira A. Técnica de perfusão para colheita de Schistosoma mansoni em cobaias experimentalmente infestadas. Revista Brasileira de Malariologia e Doenças Tropicais 8: 589597, 1956.

11. Sher A, Hieny S, James SL, Asofsky R. Mechanisms of protective immunity against Schistosoma mansoni infection in mice vaccinated with irradiated cercariae. II. Analysis of immunity in hosts deficient in T lymphocytes, B lymphocytes, or complement. Journal of Immunology 128: 1880-1884, 1982.

12. Tendler M, Brito CA, Vilar, MM, Serra-freire N, Diogo CM, Almeida MS, Delbem ACB, Silva JF, Savino W, Garratt RC, Katz N, Simpson AJG. A Schistosoma mansoni fatty acid-binding protein, SM14, is the potential basis of a dual-purpose anti-helminth vaccine. Proceedings of National Academy of Science USA 93: 269-273, 1996.

13. Tendler M, Pinto RM, Lima AO, Savino W, Katz, N. Vaccination in murine schistosomiasis with adult worm-derived antigens: variables influencing protection in outbred mice. International Journal for Parasitology 21: 299-306, 1991.

14. Wynn TA, Reynolds A, James S. IL-12 enhances vaccine-induced immunity to schistosomes by augmenting both humoral and cellmediated immune responses against the parasite. Journal of Immunology 157: 4068-4078, 1996. 